\title{
SOSIALISASI MANAJEMEN MARKETING ONLINE MENGGUNAKAN BLOG PADA UMKM JASA PENJAHIT BAJU DI PASAR PADAYUNGAN KOTA TASIKMALAYA
}

\author{
Lia Yulia*, Irfan Faris Rudiana \\ Fakultas Ekonomi Universitas Galuh \\ *Email: liayuliafeunigal@gmail.com
}

\begin{abstract}
ABSTRAK
Permasalahan yang dihadapi pada jasa usaha menjahit baju ini adalah mitra tidak terlalu fokus pada pengembangan pengelolaan pemasaran, mitra lebih mengandalkan sistem pemasaran konvensional, dan lokasi usaha yang tidak terlalu strategis. Hal ini menyebabkan bidang usahanya sulit dikenal oleh masyarakat luas sehingga menjadi kendala dalam mengembangkan usahanya. Kegiatan ini bertujuan utuk memberikan solusi mengenai permaslahan yang sedang dihadapi yaitu dengan menerapkan manajemen marketing menggunakan media internet (online). Dengan adanya sosialisasi dan pelatihan manajemen pemasaran secara online ini diharapkan dapat menambah wawasan para pelaku UMKM dalam memanfaatkan internet sebagai media promosi online untuk memperkenalkan bidang usahanya pada masyarakat luas dalam meningkatkan omzet usahanya. Hasil kegiatan ini adalah para pelaku bisnis khususnya bidang jasa penjahit baju di pasar Padayungan Kota Tasikmalaya memiliki pengetahuan dalam menggunakan media sosial dan internet sebagai sarana dalam mempromosikan bidang usahanya.
\end{abstract}

Kata kunci: Manajemen pemasaran online, UMKM jasa penjahit baju

\section{PENDAHULUAN}

Penjahit Rumah Mode (RM) telah beroperasi lebih dari 20 tahun dan memiliki tempat usaha di berada di pasar Padayungan Kota Tasikmalaya.

Penjahit RM mengalami kendala dalam memasarkan produknya yang disebabkan oleh terbatasnya konsumen pengguna jasanya, lokasi usaha yang kurang strategis sehingga konsumen sulit menemukan lokasi usahanya, dan mahalnya biaya promosi melalui iklan di radio dan surat kabar sehingga penjahit RM hanya mengandalkan banner yang dipasang di depan tokonya sebagai media promosi. Selain itu, penjahit RM memiliki keterbatasan pengetahuan dalam menggunakan jaringan internet dan media sosial (medsos) sebagai media promosi dalam menunjang kegiatan usahanya.

Tujuan dari kegiatan ini adalah: (1) Memberikan pelatihan manajemen marketing online menggunakan blog untuk mengembangkan pemasaran usahanya, (2) Memberikan pelatihan untuk memanfaatkan medsos sebagai sarana dalam memperluas jangkauan pemasaran usahanya, dan (3) Memberikan pelatihan membuat blog dan medsos dalam meningkatktkan pemasaran usahanya.

\section{BAHAN DAN METODE}

Khalayak sasaran adalah para pelaku usaha UMKM dan masyarakat desa yang memiliki mata pencaharian yang berkaitan dengan para pelaku UMKM di Pasar Padayungan Kota Tasikmalaya. 
Sosialisasi Manajemen Marketing Online Menggunakan Blog pada Umkm Jasa Penjahit Baju di Pasar Padayungan Kota

Pelaksanaan kegiatan pengabdian kepada masyarakat ini dibagi menjadi beberapa tahapan diantaranya:

1. Sosialisasi Program

Sosialisasi program dilaksanakan dengan mengadakan pertemuan awal kepada ketua desa Padayungan. Hal ini ditunjukan agar kegiatan pengabdian dapat diketahui oleh seluruh UMKM sehingga tujuan dan kegiatannya bisa berjalan dengan lancar.

2. Penyuluhan

Penyuluhan bertujuan untuk memberikan pengetahuan kepada UMKM tentang pentingnya mengenal teknologi dan memanfaatkannya dengan baik karena banyak manfaat yang diperoleh apabila para UMKM bisa menggunakan teknologi sehingga bisa mengembangkan usahanya lebih besar lagi.

3. Pelatihan

Proses pelatihan pembuatan blog menggunakan gadget dilakukan untuk meningkatkan pengetahuan para pelaku UMKM dalam menggunakan media blog sebagai sarana pemasaran bidang jasanya agar dapat menjangkau pasar lebih luas lagi dalam mendapatkan konsumen.

\section{HASIL DAN PEMBAHASAN}

\section{Sebelum Pengabdian}

Setiap orang pasti memiliki potensi untuk dikembangkan, namun ada permasalahan yaitu kurangnya kesadaran masyarakat dalam mengolah serta menggunakan teknologi untuk mengembangkan potensi yang dimiliki dirinya. Produk yang dihasilkan oleh penjahit RM terbilang cukup halus dan rapih yang seharusnya dapat menjadi modal utama dalam pengembangan usahanya, namun sampai saat ini usahanya tidak mengalami peningkatan karena belum memanfaatkan fasilitas teknologi apapun dalam memasarkan usahanya,

Permasalahan yang sering dihadapi oleh para pelaku UMKM berupa permasalahan sumber daya manusia, operasional, pemasaran, peraturan, keuangan, dan mentalitas pengusaha UMKM.

1. Permasalahan sumber daya manusia

Sumber daya manusia merupakan titik sentral yang sangat penting untuk maju dan berkembang, sebagian besar usaha mikro dan usaha kecil tumbuh secara tradisional dan merupakan usaha turun temurun namun keterbatasan sumber daya manusia usaha mikro dan usaha kecil baik dari segi pendidikan formal maupun pengetahuan dan ketrampilan sangat berpengaruh terhadap rendahnya produktivitas usaha dan tenaga kerja, misalnya 
ketidakmampuan dalam hal manajemen usaha, seperi pembukuan atau pencatatan sehingga akan menjadi suatu masalah dan harus mengadakan pelatihan kecil yang bisa memakan biaya lebih.

2. Permasalahan operasional

Masalah operasional pada usaha kecil hanya ditangani oleh sendiri sehingga teknik yang digunakan hanya sederhana, sedangkan usaha menengah memiliki sistem organisasi yang lebih besar sehingga keputusan tidak bisa ditentukan oleh satu pihak dan harus sering melakukan evaluasi agar dapat mencegah terjadinya masalah yang timbul di dalam pengelolaan suatu usaha.

3. Permasalahan pemasaran

Permasalahn pemasaran yaitu kurangnya wawasan bagi para pelaku UMKM dalam menguasai teknologi, masih kurang berinovasi dalam memasarkan produk yang dijual meskipun kebutuhan tersebut membutuhkan biaya yang relatif besar namun jika tidak dipedulikan akan menjadi masalah terbesar dalam usahanya.

4. Permasalahan peraturan

Banyak para UMKM yang belum memiliki badan hukum yang jelas, sehingga para UMKM juga kurang memiliki pengetahuan tentang aspek legalitas dan perizinan termasuk persyaratan serta prosedur yang ditempuh dalam proses pengurusan membangun suatu usaha.

5. Permasalahan Keuangan

Permasalahan keuangan bagi para UMKM yaitu kurangnya modal atau pendanaan akibatnya para UMKM mengalami kesulitan dalam meningkatkan kapasitas usahanya atau dapat mengembangkan produk-produk yang mampu bersaing dengan pengusaha lainnya.

6. Permasalahan Mentalitas pengusaha UMKM

Permasalahan ini yang membuat semangat pengusaha itu sendiri bisa berkembang berani terus berinovasi, ulet tanpa menyerah serta berani mengambil resiko akan menjadi keberhasilan namun bila sebaliknya seorang pengusaha tidak berani mengambil resiko dan mudah menyerah justru akan menjadi masalah utama dalam proses berwirausaha.

\section{Pengembangan Produk dan Jasa}

Pengembangan produk dan jasa ini dimaksudkan untuk mengembangkan produk dan jasa melalui penggunaan atribut produk, pemberian merek, pengemasan, dan jasa pendukung produk. 
Sosialisasi Manajemen Marketing Online Menggunakan Blog pada Umkm Jasa Penjahit Baju di Pasar Padayungan Kota Tasikmalaya

Lia Yulia, Irfan Faris Rudiana

1. Atribut produk

Dalam pengembangan suatau produk atribut produk sangat penting misalkan dengan menggunakan kualitas produk yang bagus, Fitur-fitur produk yang menarik serta rancangan produk yang bagus.

2. Pemberian merek

Dalam pemberian merek pengusaha harus memilih merek yang sesuai dengan produk yang akan dijual serta dapat menarik konsumen, mudah diingat, mudah diucapkan dan ringkas, sebab pemberian nama atau label bagian dari doa, harapan, cita-cita, bagian nama sendiri maupun nama keluarga karena fungsi pemberian merek yaitu mengidentifikasi produk atau merek, mencerminkan produk serta mempromosikan produk melalu gambar ataupun tulisan.

3. Pengemasan

Pengemasan suatu produk sangat penting karena merupakan wadah atau pelindung suatu barang agar barang atau produk dapat mempertahankan mutu, memperpanjang masa penyimpanan, atau pemasaran yang jika kemasannya kurang menarik konsumen tidak akan tertarik pada barang atau produk yang dijual meskipun produknya bagus dan berkualitas. Jadi pengusaha harus memikirkan kemasan seperti apa agar konsumen tertarik, misalnya gambar pada kemasan yang simpel namun elegan seperti warna tulisan yang bagus serta mudah dibaca, jelas, tidak terlalu kecil atau terlalu besar sehingga menambah daya tarik bagi konsuman.

4. Jasa pendukung produk

Perusahaan harus merancang produk dan jasa pendukungnya untuk memenuhi kebutuhan pelanggan secara menguntungkan misalnya adanya jasa pengiriman barang sehingga memudahkan konsumen seta dapat meningkatkan usahanya demi mendapatkan keuntungan atau laba yang diinginkan.

\section{Pelaksanaan Pengabdian}

Pelaksanaan pengabdian dimulai dari tahap persiapan, pelaksanaan, monitoring dan pelaporan selama beberapa bulan dan tahap demi tahap dilaksanakan sesuai rencana. Tahap pertama: adalah persiapan dengan melakukan survey ke lokasi pasar Padayungan dan melakukan wawancara dengan para pengusaha jasa menjahit baju, hasil wawancara didapatkan data awal yaitu hampir semua penjahit baju belum menggunakan teknologi sebagai media untuk mendukung kegiatan usahanya. Tahap kedua: permohonan ijin pelaksanaan kegiatan kepada kepala Desa Padayungan Kota Tasikmalaya. Tahap ketiga: 
penentuan waktu pelatihan yaitu bulan Pebruari 2019 bertempat di rumah warga sekitar. Tahap keempat: Penyiapan materi pelatihan, mulai dari langkah-langkah membuat e-mail, membuat blog dan membuat medsos facebook, twitter, dan instagram, sebagai media untuk mempromosikan blog. Tahap kelima: pelaksanaan sosialisasi dan pelatihan, dan Tahap keenam: masing-masing peserta telah memiliki alamat blog sebagai toko online untuk selanjutnya di isi dengan produk-produk dari usaha jasanya, mulai dari model baju, harga, jadwal pengerjaan dan lain sebagai nya.

\section{Setelah Program Pengabdian}

1. Hasil dari sosialisasi dan pelatihan nanajemen marketing online menggunakan blog adalah terbukanya pengetahuan para peserta dalam memanfaatkan teknologi internet dan jejaring sosial untuk mendukung kepentingan usahanya. Para peserta mulai aktif memperkenalkan bidang usaha jasanya dan dapat dengan mudah berkomunikasi dengan pelanggan pengguna jasanya.

2. Para pelaku UMKM dapat memahami dan lebih memanfaat teknologi agar mempermudah akses pemasarannya.

3. Memberikan wawasan untuk menjadi seorang entrepreneur sejati karena seorang entrepreneur bukan sekedar berdagang atau berjualan produk atau jasa saja, tetapi mampu menambah nilai suatu barang/jasa dari yang tidak berharga menjadi berharga atau bernilai.

4. Para UMKM dapat memahami penggunaan internet dan fasilitas blog untuk digunakan sebagai media marketing online agar dapat dengan mudah mendapatkan konsumen dan dapat bersaing dengan pengusaha jasa lainnya.

5. Menumbuhkan motivasi kepada para pengusahan dan calon pengusaha untuk bisa mengembangkan kegiatan.

a. Merencanakan produk/jasa yang akan di jual.

b. Bagaimana cara mempromosikan produk/jasa yang di hasilkan nya

c. Menghitung berapa keuntungan dari hasil produk/jasa yang di hasilkan nya

\section{KESIMPULAN DAN SARAN}

\section{Kesimpulan}

Masyarakat sasaran kegiatan telah memahami pentingnya media promosi pemasaran secara online dalam memunjang kegiatan pemasarannya. Selain itu, mereka telah mampu membuat blog dan mengoperasikannya dalam menunjang pemasaran produknya. 
Sosialisasi Manajemen Marketing Online Menggunakan Blog pada Umkm Jasa Penjahit Baju di Pasar Padayungan Kota

Tasikmalaya

Lia Yulia, Irfan Faris Rudiana

\section{Saran}

Saran yang diajukan dalam kegiatan pengabdian masyarakat ini adalah sebagai berikut:

1. Diharapkan aparat setempat khususnya pihak desa membentuk kelompok atau badan usaha agar dapat saling bertukar fikiran untuk pengembangan usahanya serta memunculkan ide-ide kreatif .

2. Pihak desa secara berkala mengadakan pelatihan-pelatihan bagi para entrepreneur yang baru memulai usahanya sehingga menumbuhkan semangat dan keyakinan dalam memulai suatu usahanya.

\section{DAFTAR PUSTAKA}

Al Fatta, H. (2009). Analisis dan Perancangan Sistem Informasi untuk keunggulan Bersaing Perusahaan dan Organisasi Modern.

Armstrong \& Kotler. (2004). Prinsip-prinsip Pemasaran. Edisi ke 12, Jilid 1. Jakarta: Erlangga.

Boone, Louis E., and Kurtz, David L. (2005). Contemporary Marketing. Ohio: Thomson South Western.

Santosa, M.H. (2015). Pemanfaatan Blog (jurnal online) dalam pembelajaran menulis. Bali: Universitas Pendidikan Ganesha.

Setiawati, I. (2017). Peran media sosial sebagai upaya pemasaran bisnis online (perspektif kualitatif). STMIK HIMSYA.

Kotler, P. and Keller, K.L. (2016). Marketing Management. 15thEdition New Jersey: Pearson Pretice Hall, Inc.

Station, W.J. (1999). Prinsip Manajemen Pemasaran. Jakarta: Erlangga.

Kotler, P. (2001). Manajemen Pemasaran: Analisis, Perencanaan, Implementasi dan Kontrol. Jakarta: PT. Prehallindo.

Undang-undang No. 20 tahun 2008 tentang UMKM yang terkai dengan pengembangan daya saing UMKM Pasal 1 ayat (9) dan ayat (10).

Peraturan Undang-Undang No. 20 tahun 2008 pasal 1 tentang usaha mikro, kecil dan menengah. 